\title{
MANNER OF USAGE AND EVALUATION OF INFORMATION ON THE COVID-19 PANDEMIC BY CITIZENS OF BOSNIA AND HERZEGOVINA WITHIN THE CONTEXT OF FIVE CORE CONCEPTS OF MEDIA LITERACY
}

\section{Dragana Trninić}

PRELIMINARY REPORT / DOI: 10.20901/ms.12.23.4 / SUBMITTED: 28.6.2020.

\section{ABSTRACT}

The COVID-19 pandemic has fully revealed the significance of media literacy. A great amount of fake news, as well as information lacking background, has been distributed. The paper aims to determine the manner of usage and evaluation of information on the COVID-19 pandemic in Bosnia and Herzegovina within the context of five core concepts of media literacy. The results of the survey conducted online, have shown that the majority of respondents resorted to the Internet in their search for information, that they were confused by the sheer amount of information, that they often failed to double-check it, and that they were often not able to recognise any offensive content in it.

\section{KEYWORDS}

BOSNIA AND HERZEGOVINA, MEDIA LITERACY, DISINFORMATION, FAKE NEWS, COVID-19 VIRUS

Author's note

Dragana Trninić :: Faculty of Political Sciences, University of Banja Luka :: dragana.trninic@fpn.unibl.org 


\section{INTRODUCTION}

By all means, the notion of media literacy is not a novel one and the emergence of new media has certainly had no impact on its essence, since it incorporates the features of critical approach, analysis, evaluation, and media content production, regardless of the fact whether we have traditional or new media in mind. It is a discipline providing a special frame for critical questioning and media production, founded simultaneously by Len Masterman in the UK and Barry Duncan in Canada. The first core concepts were presented in 1989 (Masterman, 1989), and they still remain central to the paradigm and conceptual frame of teaching media literarcy in global terms (Jolls \& Wilson, 2014). In 1987, in Ontario (Canada), Duncan and the Association for Media Literacy (AML) developed the ideas based on Masterman's work into eight core concepts of media literacy:

1. All media are constructions; 2. The media construct reality; 3. Audiences questioncontent/messages in the media; 4 . The media have commercial implications; 5. The media contain ideological messages and opinions; 6 . The media have social and political implications; 7. The form and content are closely connected to each other in the media; and 8. Every medium has its own aesthetic form. (Wilson \& Duncan, 2008, p. 129)

These eight core concepts still provide a theoretical background for developing media literacy. In 1989, this concept was furthered by J. Francis Davis, who wrote an article in which he presented five ideas concerning teaching children about media. Consequently, the article served as a prelude to Elizabeth Thoman, who founded the Centre for Media Literacy (CML) in 1989, to develop five concepts of media literacy:

1. All media messages are 'constructed'; 2 . Media messages are constructed using a creative language with its own rules; 3 . Different people experience the same message differently; 4 . The media have embedded values and points of view; and 5 . Most media messages are organised to gain profit and/or power. (Thoman \& Jolls, 2004, p. 23)

Thoman describes the action learning model, based on the work of Paulo Freire, a Brazilian educator (Paulo Freire Institute, 2014), and sums it up in four steps: process of empowering consciousness, analysis, reflection, and action. Through these four steps, individuals or groups can formulate a constructive idea, an action that will lead towards changing their media choice and their habits concerning the usage of media at local, national, and global levels (Thoman, 1993).

In 2000, Tessa Jolls, who joined the CML as an executive managing director in 1998, introduced novelties into the aforementioned core concepts, by concluding that children find it difficult to learn about media literacy by virtue of notions, and that they would be much more comfortable in this respect if they dealt with questions instead (Jolls \& Wilson, 2014). For that purpose, the CML puts all these elements together (the basic definition of media literacy, empowering of the spiral of consciousness, analysis, reflection, action, and 
a set of questions for children and the young, as well as for experienced practitioners of media literacy), in order to visually connect the concepts for the first time (Thoman et al., 2002). The core questions are:

1. Who created a media message? 2. What creative techniques are used for drawing attention? 3. How is it possible for different people to understand the same message differently? 4. What values, way of life, and viewpoints are reflected in or left out of the message? 5. Why was the message sent? (Thoman \& Jolls, 2004, p. 24)

Given the fast development and progress of technology enabling an instant video production, sharing content through social media, and multitude of other possibilities, the Concept of media literacy has been broadened in that the latest version of the CML's Core concept and Core questions, nicknamed Questions/TIPS (Q/TIPS), is characterised by addition of Five core questions for building (creating) media content (Jolls, 2007).

Table 1. CML's Questions / Tips

\begin{tabular}{|c|c|c|c|c|}
\hline$\#$ & Key Words & $\begin{array}{l}\text { Deconstruction: } \\
\text { CML's } 5 \text { Key Questions } \\
\text { (Consumer) }\end{array}$ & $\begin{array}{l}\text { CML's } 5 \text { Core } \\
\text { Concepts }\end{array}$ & $\begin{array}{l}\text { Construction: } \\
\text { CML's } 5 \text { Key Questions } \\
\text { (Producer) }\end{array}$ \\
\hline 1. & Authorship & $\begin{array}{l}\text { Who created this } \\
\text { message? }\end{array}$ & $\begin{array}{l}\text { All media messages } \\
\text { are constructed.? }\end{array}$ & What am I authoring? \\
\hline 2. & Format & $\begin{array}{l}\text { What creative techniques } \\
\text { are used to attract my } \\
\text { attention? }\end{array}$ & $\begin{array}{l}\text { Media messages are } \\
\text { constructed using a } \\
\text { creative language with } \\
\text { its own rules. }\end{array}$ & $\begin{array}{l}\text { Does my message reflect } \\
\text { understanding in format, } \\
\text { creativity and technology? }\end{array}$ \\
\hline 3. & Audience & $\begin{array}{l}\text { How might different } \\
\text { people understand this } \\
\text { message differently? }\end{array}$ & $\begin{array}{l}\text { Different people } \\
\text { experience the same } \\
\text { media message } \\
\text { differently. }\end{array}$ & $\begin{array}{l}\text { Is my message engaging } \\
\text { and compelling for my } \\
\text { target audience? }\end{array}$ \\
\hline 4. & Content & $\begin{array}{l}\text { What values, lifestyles } \\
\text { and points of view are } \\
\text { represented in or omitted } \\
\text { from this message? }\end{array}$ & $\begin{array}{l}\text { Media have embedded } \\
\text { values and points of } \\
\text { view. }\end{array}$ & $\begin{array}{l}\text { Have I clearly and } \\
\text { consistently framed } \\
\text { values, lifestyles and } \\
\text { points of view in my } \\
\text { content? }\end{array}$ \\
\hline 5. & Purpose & $\begin{array}{l}\text { Why is this message } \\
\text { being sent? }\end{array}$ & $\begin{array}{l}\text { Most media messages } \\
\text { are organized to gain } \\
\text { profit and/or power. }\end{array}$ & $\begin{array}{l}\text { Have I communicated my } \\
\text { purpose effectively? }\end{array}$ \\
\hline
\end{tabular}

Source: CML's Questions/TIPS (Q/TIPS), Center for Media Literacy (www.medialit.org) in Jolls \& Sund, 2007, p. 8 
Image 1. features Concepts referring to deconstruction and construction (Jolls \& Sund, 2007). This graphic display provides any individual with a quick and clear frame for analysing any media text in any media. As a result, the young can, through practice, apply this frame to their role of both media consumers and producers, and establish, over the course of time, habits of critical thinking (Jolls\& Wilson, 2014).

\section{FIVE CORE CONCEPTS OF MEDIA LITERACY WITHIN THE CONTEXT OF COVID-19 PANDEMIC}

It is important to understand each of the aforementioned concepts of media literacy in order to successfully apply it to deconstruction of media content. With regard to this, when one reads a piece of news, or hears or watches some content, one should take these concepts into consideration if one is to better understand their context, to make sure they are verified, or to use them properly.

1. AUTHORSHIP - If all media messages are 'constructed', it does not mean that they are fabricated, but only that they are put into certain context and presented from the point of view of the sender (the media, individual, group, etc.). For this reason, the first issue to be raised during the process of deconstruction is that of authorship: Who created this media message, is it public or commercial media? Who is the owner? Who is, actually, the author of the message: a journalist (media organisation) or some other organisation, a political party, an individual, or a certain lobby? The answers to all these questions are available to the recipient of the message by their closely interpreting the text. Whether it is a piece ofnews, or a billboard on a street, or a political campaign flyer, the media message in question is created by an individual (or, most likely, by a group of people), with the pictures shot and photoshopped and the text written and edited, all put together to make a single product. Yet, the words, pictures, and constructions left out and rejected are beyond reach for us as an audience. We only see, hear, and read what has been accepted. With thisin mind, what is important for critical thinking is a recognition that whatever it is that several people 'construed' becomes 'the way it is' for the rest of us. Helping people understand the process of creating media content and things that can be left out during that process, as well as the way the media shape the world we live in, is the crucial first step in accepting the fact that media constructions are not natural. Contrary to an established opinion, the media are neither a window into the world nor a reflection of the real world. It is, in fact, a carefully designed cultural product (Thoman \& Jolls, 2004). If the text we are reading is not authored, with no references to its source or with no clear instructions as to how to trace back the original text, such content should be double-checked (whether this piece of information has been released by other media as well or whether its source has been cited) and not shared or published on any platform. With reference to the COVID-19 pandemic, the media released information (depending on the source) that the virus was 'created' in China, the USA, or the UK. It was not an official piece of information, but, rather, some politicians qualifed it as either 'Chinese', 'American', or 'British' instead. Statements of this kind cannot be taken as objective since they lack scientific background. Instead, on such occasions, we should turn to an expert opinion, preferably from multiple sources. 
It is the level of our media literacy that our selection of information source depends on. With regard to this, the information we use should be taken from relevant sources, such as official institutions and organisations.

2. FORMAT - Media messages reach us in all sorts of formats: text, photograph, audio recording, video footage, various digital forms featuring numerous creative techniques in order to amplify the effect of a message or draw our attention to a certain segment of the message so we would fail to observe what is really important or missing. This is why we should ask ourselves the second core question: What creative techniques have been used to draw our attention? This issue is implied by the concept stating that media messages are 'constructed' by using a creative language based on its own rules, and it questions the components used during a construction of words, music, pictures, colour, movement, camera angle, etc. Most forms of mass communication, whether taking place by means of printed media, TV shows, horror movies, or alike, depend on the type of 'creative language'. For instance, 'frightening' music amplifies fear, close-up camera shots convey intimacy, whereas large headlines point to the significance of a piece of information in question. Understanding the grammar, syntax, and metaphoric system of the media, especially its visual language, not only helps us become less susceptible to manipulation, but it also increases our respect for and indulging into the media as a construed cultural product. The best way for one to understand the creation of media content is to do it themselves: to create a video release, a website, or a commercial (Thoman \& Jolls, 2004).

If we are exposed to content using enlarged photographs displaying inappropriate material, a footage containing disturbing images, or a large, vague, sensationalist headline offering no information but luring us into reading the textas a technique for drawing attention, we are certain not to find any verified and useful piece of information in them. During the COVID-19 pandemic, the following headlines appeared: "Killer-virus shows no signs of letting up", "Catastrophic death toll of COVID-19", "More terrifying news coming", "No end to pandemic in sight", "Be prepared for the worst" etc., followed by disturbing photographs from hospitals or by unauthentic video footages. For instance, a video footage featuring some Chinese eating bats, used to support the claim of the origin of the virus, which was later disproved, given that the video was not shot in China. On the opposite, the media that release verified information use clear, informative headlines, with the text followed by appropriate photographs or videos.

3. AUDIENCE - Different people experience the same media message in a different way. The way we interpret a piece of information depends on ourselves, our knowledge and experience, our current role/position, education, economic status, sex, race, nationality, sexual orientation, ethnic and religious designation, environment, family, and a series of other factors. Within this context, we should raise the following issue upon construction or deconstruction: In what way are different people going to experience the same message? This is particularly important when certain content is shared. This issue refers to the notion of what we are, what determines us, impacts our understanding of a media text. Each member of an audience informs a media text by a unique set of their life experiences (age, gender, education, moral education), which, when applied to the 
text in question or in combination with it, creates a unique interpretation. We may not be aware of it, but most of us (even children) constantly try to find sense in what we read, watch, or hear. The more questions we ask about how we and other people experience messages around us, the more ways there are for us to accept or reject them. Listening to someone else's interpretations may contribute to us respecting other cultures and taking into consideration opinions of minority groups (Thoman \& Jolls, 2004). That way, a piece of news announcing that certain countries have banned all religious gatherings and services, with a view to preventing disease spread, is not likely to affect believers and atheists in the same way. Similarly, there has been increased discrimination of certain professions, races, and nations/peoples during this pandemic. With regard to this, the first case of discrimination against Chinese nationals in Bosnia and Herzegovina was recorded on 26 January 2020, when the Izdvojeno.ba news portal released an article teeming with disinformation on the COVID-19 virus and the ways it spread, demanding for Chinese tourists to be banned from entering Bosnia and Herzegovina. The article fueled unsubstantiated fears on the basis of racial constructions. Furthermore, there have been threats and calls for violence registered on the Facebook in relation to the pandemic, with the authorities taking prompt actions and identifiying and processing the perpetrators (The Balkan Investigative Network-BIRN and SHARE Foundation, 2020, p. 10). In case of isolation as a pre-emptive social measure, a specific situation humans are unaccustomed to, additional caution needs to be taken upon creating and sharing media content, given the fact that what we find amusing might be considered disturbing by someone else, causing fear and spreading panic. In this respect, we must be aware of the fact that it is the recipient who is the final interpreter of the message. We may have the best intention, but the recipient could take in a different way. For thisreason, it is important that we remain responsible in this respect and always take the position of a possible recipient, asking ourselves what sentiments our message might cause.

4. CONTENT - The media, with regard to their content, promote certain points of view, values, opinions, ways of life, whereas they remain ignorant of others. Whenever we approach certain media content, we should ask ourselves the following: What values/ points of view are promoted in or left out from the message? With reference to these points of view, there are concerns about them being unilateral, as well as about their origin and their advocates (experts, official sources, or certain individuals). In the end, we should ask ourselves what values have been left out and why. This issue deals with content of a media message, starting from the core concept of the media 'installing' certain points of view and opinions into its content. Upon construction of media messages, choices must be made that inevitably reflect the values, opinions, and points of view of those who construct them. The decision on incorporating the features of age, gender, or race into a message, combined with those of lifestyle, opinions and behaviour presented, together with the selection of social environment (urban, rural, high-end, low-end) and action and counter-action in certain situations, represent some of the ways of 'embedding' values into TV shows, films, and commercials. News programmes are no exceptions to this rule, with values being 'embedded' in the news by means of decisions being made on major/ lead stories, their duration, photographs to follow etc. What is important with regard to this issue is not the fact that ideas and values have been 'embedded', but the fact that 
the information burdened with the aforementioned values amplifies or changes the way in which we interprete the world around us. If we are equipped with skills to rationally identify clear and latent values in a mediated message, either coming from the media or our colleagues, we are more likely to be much more tolerant towards differences and much more selective upon deciding whether to accept or reject the message on the whole. An ability to recognise missing perspectives is another critical skill as well (Thoman \& Jolls, 2004).

When we find certain media content suspicious in terms of openly advocating for a political option and of promoting quacking, without a genuine meaning of the message being expressed clearly, without scientifically credible sources to support them, and stripped of public interest, we should compare them against different sources and thus provide ourselves with the complete image of the event in question. Any piece of information expressing unilateral points of view should be approached critically. With regard to the COVID-19 pandemic, there have been strange and unverified pieces of news claiming that shipments from China are dangerous, that the disease could be treated and prevented by eating garlic and drinking alcohol (which was disproved by the World Health Organisation), along with numerous instances of fake news spreading panic (such as those referring to possible lockdown of cities and lack of basic provisions in stores).

5. PURPOSE - Although it is a known fact that the public media should release content of public interest (and not the content the public is interested in), the fifth core concept tells us that all media messages are sent with a view to gain profit and/or power. Therefore, there is a desire for either gaining profit and/or power behind every media message (Thoman and Jolls, 2004). Almost every medium, both public and commercial, is financed partly or on the whole by advertisers, depending on its ownership structure. In order for a medium to find advertisers, it must provide an audience which, in turn, guarantees advertisers. With this in mind, it is clear that there is a desire for profit behind most messages, or at least behind the way they are created. That is what urges us to pose the following question: Why was the message sent?

This concept deals with the motivation behind or purpose of a media message, and it serves to determine whether a message can be influenced by money, ego, or ideology, and in what way. Today, a great deal of global mass media companies operate as commercial enterprises, and this fact helps us evaluate whether a message is profit-driven. Many people find a commercial influence more acceptable when the media company offering entertainment content is concerned, in comparison to the one producing news. Given the development of democracy, every citizen should be familiar with a possible impact of economy and ideology on all media content. As for the issue of motivation, it has drastically changed with the emergence of the Internet, where many people have access to powerful tools that can be used to persuade others into their points of view. The Internet offers an opportunity to users from all age groups to notice instances of inadequate reasoning, to check for an information source, and to evaluate the quality of a research (Thoman \& Jolls, 2004). 
In addition, it is important to question whether the media content we are using contains information of public interest and to look into the way they are presented. If a message is lacking elements of public interest or if they are presented in a sensationalist and unethical manner (for instance, information on public health that violates the right to privacy, offends someone's feelings, or contains disturbing content), we should not use or share such content, but seek information from official sources (such as the Ministry of Health, the Institute of Public Health, the WHO etc.).

During this pandemic, there have been cases recorded in the media of disclosing identity of people tested positive for COVID-19 and their subsequent stigmatisation, of ridiculing the pandemic, and of certain measures undertaken by respective countries and the World Health Organisation in order to control the spread of virus. Such approach to this phenomenon is both unprofessional and unethical. In April 2020, two nurses employed with the University Clinical Hospital in the city of Mostar (Federation of Bosnia and Herzegovina) took shots of patients and shared this content. In this material, the faces and identities of the patients can be clearly seen and recognised (The Balkan Investigative Network-BIRN and SHARE Foundation, 2020, p. 5).

\section{METHODOLOGY}

The research was conducted between 27 April and 5 May 2020. It aims at determining the way in which citizens of Bosnia and Herzegovina gather information on the COVID-19 virus during the pandemic and especially: a) what sources they find credible, b) are they confused by the sheer amount of information, c) are they able to recognise fake news, a fake video material, or a fake photograph, and d) can they identify pieces of news on COVID-19 whose release violates the right to privacy or whose content might be offensive for some viewers.

The data are gathered by an online survey using the Google forms programme (www. google.com/forms/about/). This type of research is a result of inabillity to organise a research that includes a physical contact, due to restrictions concerning public gatherings and freedom of movement. The data was gathered using an adequate sample of 1,151 respondents, with application of an online/offline sample taking - the sample is created by contacting the respondents and directing them to the Internet to fill in a questionnaire (Popadić et al., 2018). Not all respondents are contacted in person, but the technique of snowball sampling is applied (Milosavljević \& Radosavljević, 2013). The link leading to the online study was delivered to around 1,500 accounts of major citizens from 95 municipalities in Bosnia and Herzegovina, with limitations imposed on the process by allowing to send only one questionnaire from a single account, thus eliminating multiple participation in the survey.

The instrument used for conducting the survey is a formalised (standardised) questionnaire with precisely defined questions and modalities of answers offered (Milosavljević \& Radosavljević, 2013). Some questions required a single answere while 
some offered the option of multiple answers. Questionnaire included 15 questions in total: questions regarding general data of the respondent, questions regarding the way and frequency of acquiring information on COVID-19, and questions regarding the credibility of sources, sharing content, and recognising fake news, fake video materials and fake photographs concerning COVID-19. The process of formatting and designing of the questionnaire is adapted to an online form. An optimum number of questions is selected due to the inability of controlling the conditions and turnout rate, given that the duration of a study is a major factor of sample dwindling and abandoning an Internet research (Edwards et al., 2002).

A logical strategy of funnel type is used in organising the questionnaire sections (Milosavljević \& Radosavljević, 2013), with questions ranging from general to specific ones. Bearing in mind that much concerning a respondent is not within researcher's control (Popadić, et al., 2018), the questions referring to the legibility of respondents are listed on the homepage of the study website (for instance, people living in Bosnia and Herzegovina). The initial question of the questionnaire deals with the type of media used to gather information on COVID-19, the final one with our ability to recognise information on COVID-19 that may be offensive in terms of race, nation, or an individual's beliefs.

This research enables measuring the level of media literacy of respondents in relation to obtaining and evaluating media information in specific situations, such as the COVID-19 pandemic. In addition, it enables determining specific competences of media literacy of respondents and associating these features with their education level.

\section{DEMOGRAPHIC DATA}

One third of the respondents come from the city of Banja Luka, followed by the cities of Tuzla, Zenica, Sarajevo, Istočno Sarajevo, Mostar etc. The modal respondent is a female, holding an academic degree, aged 18-40. The majority of respondents are women (70.1\%), young, aged 18-24 (50.6\%), and academic degree holders (37.9\%) (Tables 2, 3 and 4).

Table 2. Sex structure of respondents

\begin{tabular}{cll} 
Sex & Male & Female \\
$\mathrm{f}$ & 344 & 807 \\
$\%$ & 29.9 & 70.1 \\
\hline
\end{tabular}

Table 3. Age structure of respondents

\begin{tabular}{lllllll} 
Age & $\mathbf{1 8 - 2 4}$ & $\mathbf{2 5 - 3 4}$ & $\mathbf{3 5 - 4 4}$ & $\mathbf{4 5 - 5 4}$ & $\mathbf{5 5 - 6 4}$ & Over $\mathbf{6 5}$ \\
$\mathrm{F}$ & 582 & 218 & 201 & 106 & 34 & 10 \\
$\%$ & 50.6 & 18.9 & 17.5 & 9.2 & 3 & 0.9 \\
\hline
\end{tabular}


Table 4. Education level of respondents

\begin{tabular}{lll} 
Education & f & $\%$ \\
Secondary school & 352 & 30.5 \\
College & 65 & 5.6 \\
University graduate degree & 437 & 37.9 \\
MA degree & 123 & 10.7 \\
PhD degree, PhD candidate & 174 & 15.1 \\
\hline
\end{tabular}

\section{RESEARCH RESULTS}

\section{Manner and frequency of gathering information on COVID-19}

The results show that the respondents mostly turned to online media portals in their search for information (80.2\%), followed by television (70.7\%), social media (42.4\%), and finally print media (5\%).

Table 5. Media used for gathering information on COVID-19 (multiple choice)

\begin{tabular}{lll} 
What media do you usually use for gathering information on COVID-19? & $\mathbf{f}$ & $\%$ \\
\hline Online media/ Internet portals & 924 & 80.2 \\
TV & 814 & 70.7 \\
Radio & 97 & 8.4 \\
Print media & 58 & 5 \\
Social media & 488 & 42.4 \\
Applications for exchanging messages & 96 & 8.3 \\
\hline
\end{tabular}

These results are expected, concerning the fact that this is an online study that includes respondents who use the Internet on a daily basis, and who are, at the same time, young and academically educated.

When it comes to frequency of gathering information on COVID-19, most of the respondents do it several times a week (28.3\%), $26.6 \%$ do it once or twice a day, $26 \%$ once a day while $11.1 \%$ of the respondents search for information two to three times a day (Table 6).

The data reveal that the respondents did not search for information on COVID-19 very frequently. Such results show a rational approach to gathering information, since uncontrolled and frequent gathering of information on the same phenomenon can lead to the feeling of being fed up and confused by the sheer amount of information, which is illustrated in Table 7. 
Table 6. Frequency of gathering information on COVID-19

\begin{tabular}{lll} 
How often do you gather information on COVID-19? & f & $\%$ \\
Several times a week & 326 & 28.3 \\
Once a day & 299 & 26 \\
Once-twice a day & 307 & 26.6 \\
Two to three times a day & 128 & 11.1 \\
Three to five times a day & 39 & 3.4 \\
More than five times a day & 52 & 4.5 \\
\hline
\end{tabular}

Table 7. Attitude towards the amount of information on COVID-19

\begin{tabular}{lrl} 
Are you confused by the amount of various information on COVID-19? $\mathbf{f}$ & $\%$ \\
\hline Yes, often & 367 & 31.9 \\
Sometimes & 515 & 44.7 \\
No, because I can select proper information & 269 & 23.4 \\
\hline
\end{tabular}

Most of the respondents are confused by the sheer amount of information sometimes (44.7\%) and often (31.9\%) - while $23.4 \%$ of them claim that they can select proper information. Bearing in mind that the respondents gathered information mostly on the Internet, it is likely that they were exposed to the amount of information they found hard to absorb.

\section{Double-checking and sharing information on COVID-19}

Table 8. indicates that that $33.4 \%$ of the respondents have sometimes double-checked information on COVID-19 when there was no reference to the source, $25.6 \%$ have done it often and $8.9 \%$ never.

Table 8. Checking information on COVID-19

\begin{tabular}{lll} 
Do you double-check information on COVID-19? & $\mathbf{f}$ & $\%$ \\
Yes, often & 295 & 25.6 \\
Sometimes, when there is no reference to the source & 385 & 33.4 \\
Seldom & 369 & 32.1 \\
No, never & 102 & 8.9 \\
\hline
\end{tabular}

Although the results show that a quarter of the respondents have often doublechecked information on COVID-19, and the rest sometimes, seldom, or never, it is hardly satisfying, especially when one takes into consideration the amount of disinformation and fake news released during the pandemic. In their report based on a four-month monitoring 
process of the situation related to the pandemic, the Balkan Investigative Network (BIRN) and the SHARE Foundation recorded 163 cases of digital rights violation in Bosnia and Herzegovina, Hungary, Croatia, Serbia, Romania, and North Macedonia, of which more than half are related to propaganda, disinformation, untrue content, and release of unverified data, whereas in $80 \%$ of these cases citizens were targeted as a vulnerable group. The report singles out an incident in the city of Tuzla, where a Facebook user called for destruction of an alleged 5G mobile relay network, and a release of disinformation on blood types less susceptible to COVID-19 on the Buka portal (The Balkan Investigative Network-BIRN and SHARE Foundation, 2020).

Table 9. Credibility of information on COVID-19 (multiple choice)

\begin{tabular}{|c|c|c|}
\hline \multicolumn{2}{|c|}{ How do you know that a piece of information on COVID-19 is credible? $f$} & \multirow{2}{*}{$\begin{array}{l}\% \\
23\end{array}$} \\
\hline I trust the media that released it & 265 & \\
\hline I trust the source cited & 503 & 43.7 \\
\hline There are many views & 12 & 1 \\
\hline There is a lot of liked/shared content & 10 & 0.9 \\
\hline Several media companies released the same information & 522 & 45.4 \\
\hline I do not think about it & 295 & 25.6 \\
\hline
\end{tabular}

In most cases, the respondents (45.4\%) claim that they know that a piece of information on COVID-19 is credible based on the fact that it has been released by several media companies, then based on a trustworthy source (43.7\%), whereas $25.6 \%$ did not think about it (Table 9). One can conclude that almost half of the respondents use reliable parametres for evaluating information credibility, while only several respondents resort to views, likes, and shared content as credibility parametres. Still, there is a high percentage of those who do not think about credibility - fact-checking platforms from Bosnia and Herzegovina, Croatia, and Serbia claim that the pandemic has contributed to the "flood" of disinformation on a single topic, released constantly and intensely, with "a devastating impact on people" (Pamuk, 2020, p. 3).

Table 10. Sharing information on COVID-19

\begin{tabular}{lll}
$\begin{array}{l}\text { Do you share information on COVID-19 that you are } \\
\text { not sure it is credible? }\end{array}$ & $\mathbf{f}$ & $\%$ \\
\hline Yes, often & 12 & 1 \\
Sometimes, because it might be credible & 96 & 8.3 \\
Seldom & 235 & 20.4 \\
No, never & 808 & 70.2 \\
\hline
\end{tabular}

Most of the respondents (70.2\%) have never shared pieces of information on COVID-19 if they were not sure that it was credible; $20.4 \%$ did it seldom, and only $1 \%$ often (Table 10 ). These results point to a high level of awareness of respondents on a possible harmful effect 
of sharing unverified information that can cause panic and fear among citizens. When sharing such content in an irresponsible way, there is little concern for the consequences their release might cause, since that text is intended as a clickbait (Pamuk, 2020).

\section{Identifying fake news, disinformation, photographs, and video footages featuring COVID-19}

According to the results presented in Table 11, most of the respondents (75.1\%) have encountered some instances of fake news or disinformation on COVID-19, 13.4\% of them claim they have not had that experience, while $8 \%$ of the respondents say that they are not able to tell whether a piece of information is a fake news or disinformation.

Table 11. Fake news and disinformation on COVID-19

\begin{tabular}{lll} 
Have you encountered a fake news or disinformation on COVID-19? & $\mathbf{f}$ & $\%$ \\
Yes, on several occasions & 864 & 75.1 \\
Just once & 41 & 3.6 \\
I cannot tell the difference & 92 & 8 \\
No, I have not & 154 & 13.4 \\
\hline
\end{tabular}

These results support the claim that a high percentage of the respondents can differentiate between fake news and disinformation and a credible piece of information because they have encountered such news on several occasions during the pandemic. During April 2020, the Raskrinkavanje fact-checking platform from Bosnia and Herzegovina analysed and deconstructed 68 pieces of fake news and disinformation that were released or distributed by media companies from the country.

Table 12. Fake photographs and video footages of COVID-19

\begin{tabular}{lll}
$\begin{array}{l}\text { Have you encountered a fake photograph or a video footage } \\
\text { of COVID-19 pandemic? }\end{array}$ & $\mathbf{f}$ & $\%$ \\
\hline Yes, on several occasions & 571 & 49.6 \\
Just once & 62 & 5.4 \\
I can not tell the difference & 133 & 11.5 \\
No, I have not & 385 & 33.5 \\
\hline
\end{tabular}

Nearly half of the respondents (49.6\%) have encountered fake photographs and video footages of COVID-19 on several occasions during the pandemic, 33.5\% of them claim they have not been exposed to such content, whereas $11.5 \%$ of the respondents cannot tell the difference between genuine photographs and video footages and fabricated ones (Table 12). The results suggest that half of the respondents can identify fake photographs and video footages and that they have done so on several occasions during the pandemic. It is a good indicator, given that there have been frequent cases of fake, fabricated 
photographs and video footages accompanying texts featuring COVID-19 stories. The results further suggest that half of the respondents posess media literacy competences which enables them to identify fake photographs and video footages. Still, there is some percentage of those who do not (11.5\%).

\section{Level of trust in source of information on COVID-19 and recognition of offensive and inappropriate content}

The level of trust placed in sources of information on COVID-19 is presented in Table 13. Evidently, the respondents put most trust in scientists, medical doctors, health experts (86.6\%), then international public health institutions (54\%), national public health institutions (40.2\%) and professional journalists (22.7\%). Entity authorities in Bosnia and Herzegovina are trusted only by $6.9 \%$ respondents ${ }^{1}$.

Table 13. Level of trust in sources of information on COVID-19 (multiple choice)

\begin{tabular}{lll} 
What sources of information on COVID-19 do you trust the most? & $\mathbf{f}$ & $\%$ \\
\hline Professional journalists & 262 & 22.7 \\
Bloggers & 8 & 0.7 \\
Local politicians & 24 & 2.1 \\
Scientists, medical doctors, health experts & 998 & 86.6 \\
International public health institutions & 622 & 54 \\
National public health institutions & 463 & 40.2 \\
Entity authorities & 79 & 6.9 \\
Famous public figures & 7 & 0.6 \\
Common people that inspire trust & 109 & 9.5 \\
\hline
\end{tabular}

The results demonstrate a high level of their ability to choose a relevant source of information on COVID-19. In the first place, it is scientists, experts, members of international and national public health institutions, who are far more preferred in this respect to bloggers, famous public figures and local politicians. The respondents put little trust in entity authorities as a source of information on COVID-19. Professional journalists score higher than politicians but still much lower than scientists, medical doctors and health exeperts.

Table 14 demonstrates that $58.2 \%$ of respondents perceive that they have had no experience of offensive content during the pandemic, whereas $30.6 \%$ have had on several occasions and $6.6 \%$ respondents were not able to tell the diferrence. At the same time, The Balkan Investigative Network-BIRN and SHARE Foundation argue that "during the COVID-19 pandemic, the vulnerable groups to have been exposed to threats, discrimination, and hatred campaigns have been journalists, medical workers, citizens ordered to quarantine, migrants, women, Roma, Chinese, and Jews" (2020, p. 9). Given the

\footnotetext{
$\overline{{ }^{1} \text { Bosnia }}$ and Herzegovina is comprised of two dependent administrative-political entities, the Republic of Srpska and the Federation of Bosnia and Herzegovina, and the Brčko District.
} 
fact that such offensive content permeated information on COVID-19 pandemic, a media literate audience should have recognised them.

Table 14. Information on COVID-19 that contains offensive content

\begin{tabular}{lll}
$\begin{array}{lll}\text { Have you noticed a piece of information on COVID-19 that might be } \\
\text { offensive in terms of race, nation, or an individual's beliefs? }\end{array}$ & $\mathbf{f}$ & $\%$ \\
\hline $\begin{array}{ll}\text { Yes, on several occasions } \\
\text { Just once }\end{array}$ & 352 & 30.6 \\
I cannot tell the diferrence & 53 & 4.6 \\
No, I have not & 76 & 6.6 \\
\hline
\end{tabular}

Table 15. Information on COVID-19 that violates the rights to privacy

\begin{tabular}{lll}
$\begin{array}{l}\text { Have you noticed any piece of information on COVID-19 } \\
\text { that violates the rights to privacy? }\end{array}$ & $\mathbf{f}$ & $\%$ \\
\hline $\begin{array}{l}\text { Yes, on several occasions } \\
\text { Just once }\end{array}$ & 501 & 43.5 \\
I would not know how to recognise such information & 69 & 6 \\
No, I have not & 90 & 7.8 \\
\hline
\end{tabular}

Table 15 suggests that $43.5 \%$ of the respondents have on several occasions encountered content that violates right to privacy, that $42.7 \%$ have not encountered it and that $7.8 \%$ of the respondents have not been able to recognise such content.

This may suggest that almost half of the respondents were not able to recognise content violating the right to privacy since The Balkan Investigative Network-BIRN and SHARE Foundation warned that "there have been violations of the right to protection of personal data, and among 18 cases registered there is an example from the Republic of Srpska, whose authorities started a website with daily updates on the list of persons who disrespected the measures of self-isolation" (2020, p. 5). On the other hand, it is an encouraging fact that almost half of the respondents can recognise such content, although the percentage should be considerably higher, given the dominant academic background of participants in the survey.

\section{Media competences of the respondents in relation to their sex, age, and education}

This section investigates to what extent the categories of sex, age, and education impact the media competences of respondents in relation to usage and evaluation of media information on COVID-19 pandemic. The following dependent variables are used: frequency of getting informed on COVID-19; confusion of respondents by the amount of information; checking; credibility of information and sharing; contact with fake news or disinformation; contact with fake photograph or video footage. 
Table 16. Frequency of getting informed about COVID-19 in relation to respondents' age

\begin{tabular}{|c|c|c|c|c|c|c|c|}
\hline \multirow[t]{2}{*}{ Variables } & & \multicolumn{5}{|c|}{ How often do you get informed about COVID-19? } & \multirow{2}{*}{ Overal } \\
\hline & & $\begin{array}{l}\text { Once } \\
\text { a day }\end{array}$ & $\begin{array}{l}1-2 \\
\text { times a } \\
\text { day }\end{array}$ & $\begin{array}{l}2-3 \\
\text { times a } \\
\text { day }\end{array}$ & $\begin{array}{l}3-5 \\
\text { times a } \\
\text { day }\end{array}$ & $\begin{array}{l}\text { More than } \\
5 \text { times a } \\
\text { day }\end{array}$ & \\
\hline \multicolumn{8}{|l|}{ Age } \\
\hline \multirow[t]{2}{*}{$18-24$} & $\mathrm{~F}$ & 159 & 152 & 48 & 10 & 12 & 381 \\
\hline & $\%$ & 41.7 & 39.9 & 12.6 & 2.6 & 3.1 & 100.0 \\
\hline \multirow[t]{2}{*}{$25-44$} & $\mathrm{~F}$ & 109 & 112 & 56 & 19 & 20 & 316 \\
\hline & $\%$ & 34.5 & 35.4 & 17.7 & 6.0 & 6.3 & 100.0 \\
\hline \multirow[t]{2}{*}{ Over 45} & $\mathrm{~F}$ & 31 & 43 & 24 & 10 & 20 & 128 \\
\hline & $\%$ & 24.2 & 33.6 & 18.8 & 7.8 & 15.6 & 100.0 \\
\hline \multicolumn{8}{|l|}{ Overall } \\
\hline & $\mathrm{F}$ & 299 & 307 & 128 & 39 & 52 & 825 \\
\hline & $\%$ & 36.2 & 37.2 & 15.5 & 4.7 & 6.3 & 100.0 \\
\hline
\end{tabular}

$X^{2}=44,841 ; d f=8 ; C V=0,165 ; p=0,000 ; N=825$

The chi-squared test shows that there is a difference in frequency of getting informed among the respondents distributed in three age categories $(C V=0,165)$. In addition, the difference is statistically significant ( $F=21,136$; sig. 0,000). Using multiple comparison method applied on the aforementioned three groups ${ }^{2}$, along with the use of Tukey's range test, it is determined that there is an increase in the frequency of getting informed on COVID-19 as age progresses. The oldest respondents have searched for information the most, the youngest the least, which points to a conclusion that the former wanted to be better informed since they are, in all probability, more concerned about the whole situation. The COVID-19 virus, as a new disease, caused fear and a sense of impotence in many people, resulting in citizens looking for relevant information to help them cope with the current situation.

Table 17. Consumption of information on COVID-19 in relation to education of respondents

\begin{tabular}{|c|c|c|c|c|c|c|c|}
\hline \multirow[t]{2}{*}{ Variables } & & \multicolumn{5}{|c|}{ How often do you get informed about COVID-19? } & \multirow{2}{*}{ Overall } \\
\hline & & $\begin{array}{l}\text { Once } \\
\text { a day }\end{array}$ & $\begin{array}{l}1-2 \\
\text { times a } \\
\text { day }\end{array}$ & $\begin{array}{l}2-3 \\
\text { times a } \\
\text { day }\end{array}$ & $\begin{array}{l}3-5 \\
\text { times a } \\
\text { day }\end{array}$ & $\begin{array}{l}\text { More than } \\
5 \text { times a } \\
\text { day }\end{array}$ & \\
\hline \multicolumn{8}{|l|}{ Education } \\
\hline \multirow{2}{*}{$\begin{array}{l}\text { Secondary } \\
\text { school }\end{array}$} & $f$ & 96 & 97 & 32 & 2 & 8 & 235 \\
\hline & $\%$ & 40.9 & 41.3 & 13.6 & 0.9 & 3.4 & 100.0 \\
\hline
\end{tabular}

\footnotetext{
$\overline{2}$ The dependent variable is presented as an ordinal one, featuring 6 modalities, with the modality of "Once a day" being assigned with value of 1 , and the modality of "More than 5 times a day" with value of 6 .
} 
PRELIMINARY REPORT / DOI: 10.20901/ms.12.23.4 / SUBMITTED: 28.6.2020.

\begin{tabular}{llllllll} 
College or faculty & $\mathrm{f}$ & 133 & 127 & 54 & 19 & 29 & 362 \\
& $\%$ & 36.7 & 35.1 & 14.9 & 5.2 & 8.0 & 100.0 \\
\hline $\begin{array}{l}\text { MA / PhD degree } \\
\text { or PhD student }\end{array}$ & $\mathrm{f}$ & 70 & 82 & 42 & 18 & 15 & 227 \\
Overall & 30.8 & 36.1 & 18.5 & 7.9 & 6.6 & 100.0 \\
& & & & & & & \\
& $\mathrm{f}$ & 299 & 306 & 128 & 39 & 52 & 824 \\
& $\%$ & 36.3 & 37.1 & 15.5 & 4.7 & 6.3 & 100.0 \\
\hline
\end{tabular}

$X^{2}=24,140 ; d f=8 ; C V=0,121 ; p=0,002$

The chi-squared test shows that there is a difference in frequency of getting informed among the respondents of different educational level $(C V=0,121)$. In addition, the difference is statistically significant $(F=7,560$; sig. 0,001). By means of the multiple comparison method applied to the respondents of various educational level, along with the use of Tukey's range test, it is determined that the respondents who graduated from a college or university have searched for information on COVID-19 more frequently than those who have a secondary school certificate. The results point to a conclusion that better educated respondents were more aware of the significance of being informed (Table 17).

Table 18 indicates that the respondents who earned their MA or PhD degree have had more experiences with fake photograph or video footage. This can probably be assigned to their abilities to recognise such content. This suggests that MA or PhD degree holders may have an advantage in terms of recognising fake photographs or video footages. The results potentially point to the significance of educational level in identifiying and evaluating false information.

Table 18. Contact with fake photographs or video footages concerning COVID-19 in relation to level of education

\begin{tabular}{|c|c|c|c|c|c|}
\hline \multirow[t]{2}{*}{ Variables } & & \multicolumn{3}{|c|}{$\begin{array}{l}\text { Have you ever encountered a fake photograph } \\
\text { or video footage concerning COVID 19? }\end{array}$} & \multirow[t]{2}{*}{ Overal } \\
\hline & & $\begin{array}{l}\text { Yes, on several } \\
\text { occasions }\end{array}$ & $\begin{array}{l}\text { Just } \\
\text { once }\end{array}$ & $\begin{array}{l}\text { No, I have } \\
\text { not }\end{array}$ & \\
\hline \multicolumn{6}{|l|}{ Education } \\
\hline \multirow[t]{2}{*}{ Secondary school } & $\mathrm{F}$ & 142 & 28 & 136 & 306 \\
\hline & $\%$ & 46.4 & 9.2 & 44.4 & 100.0 \\
\hline \multirow[t]{2}{*}{ College or faculty } & $\mathrm{F}$ & 253 & 23 & 174 & 450 \\
\hline & $\%$ & 56.2 & 5.1 & 38.7 & 100.0 \\
\hline \multirow{2}{*}{$\begin{array}{l}\text { MA / PhD degree, } \\
\text { or PhD student }\end{array}$} & $\mathrm{F}$ & 175 & 11 & 75 & 261 \\
\hline & $\%$ & 67.0 & 4.2 & 28.7 & 100.0 \\
\hline \multicolumn{6}{|l|}{ Overall } \\
\hline & $\mathrm{F}$ & 570 & 62 & 385 & 1017 \\
\hline & $\%$ & 56.0 & 6.1 & 37.9 & 100.0 \\
\hline
\end{tabular}

$X^{2}=26,951 ; d f=4 ; C V=0,115 ; p=0,000$ 
Finally, the analysis shows that the variable of sex has an impact on five dependent variables. Yet, the data suggest that male respondents are more educated on average than female ones, thus showing that the variable of sex actually reveals a hidden impact of a respondents' educational level. In other words, it is a false predictor. It is visible if we look up the data in Table 19, with T-test conclusive in this respect ( $T=3,694$; sig. 0,000).

Table 19. Sex of respondents in relation to educational level

\begin{tabular}{llllll} 
Variables & Education & & Overall \\
Secondary & $\begin{array}{l}\text { College or } \\
\text { facholty }\end{array}$ & $\begin{array}{l}\text { MA / PhD degree, } \\
\text { PhD student }\end{array}$ & \\
\hline School & & & & & \\
\hline Female & $\mathrm{f}$ & 89 & 140 & 115 & 344 \\
& $\%$ & 25.9 & 40.7 & 33.4 & 100.0 \\
\hline Overall & $\mathrm{f}$ & 263 & 362 & 181 & 806 \\
& $\%$ & 32.6 & 44.9 & 22.5 & 100.0 \\
& & & & & 1150 \\
& $\mathrm{f}$ & 352 & 502 & 296 & 100.0 \\
\hline
\end{tabular}

\section{CONCLUSION}

The COVID-19 pandemic has resulted in a great amount of information and media content, from articles in journals to disinformation and fake news, all in response to numerous issues raised by citizens regarding a new disease. Apart from daily reports by international and national public health institutions, statements made by medical doctors, scientists, health experts, and representatives of authorities, there has been a great amount of disinformation and conspiracy theories concerning the pandemic. The increase in the number of disinformation and fake news has been verified by numerous studies across the world (Nielsen, et al., 2020) and organisations (EUDisinfoLab, 2020), as well as national platforms for fact-checking (The Balkan Investigative Network-BIRN and SHARE Foundation, 2020; Raskrinkavanje.ba, 2020).This paper investigated usage and evaluation of information on COVID-19 by citizens of Bosnia and Herzegovina, the sources they have trusted, and whether they have been confused by the amount of information.

The issue discussed in the paper is placed within the context of five core concepts of media literacy. In addition, this concept offers five questions that could be used in the process of deconstruction of any piece of information. These questions were posed to the respondents in order to determine their media competences regarding usage, interpretation, and analysis of media content, as well as the level of trust in sources of information on the COVID-19 pandemic. 
The results show that the respondents have mostly turned to online media portals for credible information, several times a week and that they were often or sometimes confused by the amount of information. One third of the respondents have doublechecked information when they could not trace it back to a credible source, which is not a satisfying percentage, given the amount of disinformation and fake news circulating during the pandemic. Almost half of the respondents claim that their belief in the credibility of a piece of information rests upon the fact that the information has been released by several media companies and the fact that they place trust in the source of information, which are solid parametres of credibility. Most respondents have not shared information whose validity they found difficult to establish, which points to a high level of awareness of the respondents about a possible harmful effect of sharing information that can cause panic and fear among people. There is a high percentage of respondents who are able to recognise fake news and disinformation because they have encountered such content on several occasions during the pandemic. The data reveal that half of the respondents are able to recognise fake photographs. Yet, there is a relatively concerning percentage of those who are not (11.5\%).

In terms of the agents they trust the most, the respondents appraise scientists, medical doctors, health experts, international public health institutions and national public health institutions. The results show a high level of ability of respondents to choose a relevant source of information on COVID-19. Still, at the same time, the results point to a low level of ability of respondents to recognise offensive content in terms of race, nation, or an individual's beliefs, with almost half of the respondents being ignorant about the content violating the right to privacy of citizens. The oldest respondents have searched for information the most, the young the least, which indicates that the former have wanted to be better informed, given that they are, in all probability, more concerned about the whole situation. As for the respondents who hold college degrees, they have sought information more frequently than those who have a secondary school degree, which leaves us with a conclusion that the higher educated respondents are more aware of the significance of being informed. Similarly, the respondents who hold MA or PhD degree have had more experience with fake photographs or video footages during the pandemic. It can be possibly assigned to their increased ability to recognise such content.

The Questions/TIPS (Q/TIPS) model of media literacy offers a basis for deconstruction and creation of media content to all users, especially in terms of developing habits of critical thinking. The four-step action learning model - consciousness empowerment process, analysis, reflection and action (Thoman, 1993) - if applied on a regular basis, can result in the emergence of critical thinking in media users, in particular with regard to media selection and media habits. 


\section{References}

>Arao, D. A. (2020). Media literacy amid COVID-19 pandemic. Bulatlatan - Journalism for the people. https://DOI:10.13140/RG.2.2.10355.48163.

>The Balkan Investigative Network-BIRN and SHARE Foundation. (2020). From Cures to Cures, Manipulation Flourishes in the Digital Enviroment. Retrieved April 30, 2020, from https://bird.tools/ wp-content/uploads/2020/06/From-Cures-to-Curses-Manipulation-Flourishes-in-the-DigitalEnvironment.pdf.

$>$ Davis, J.F. (1989). Five Important Ideas to Teach Your Kids About TV. Media \&

Values, 52-53, Retrieved April 30, 2020, fromhttp://www.medialit.org/reading-room/

five-important-ideas-teach-your-kids-about-tv.

>Edwards, P., Roberts, I., Clarke, M., DiGuisepi, C., Pratap, S., Wentz, R.,\& Kwan, I. (2002). Increasing responserates to postalquestionnaires: Systematic review. British Media Journal, 324, 1183-1192. >EUDisinfoLab. (2020).COVID 19 Disinformation: Trends, Strategies, and Narratives in Italy, France, and Spain. Retrieved May 22, 2020, from https://www.disinfo.eu/wp-content/ uploads/2020/05/20200515_briefing-no2_FINAL-2.pdf.

>Freire Institute. (2014).Concepts used by Paulo Freire. Retrieved May 18, 2020, from http://www. freire.org/paulo-freire/concepts-used-by-paulo-freire.

>Jolls, T., \& Wilson, C. (2014). The Core Concepts: Fundamental to Media Literacy Yesterday, Today and Tomorrow. Journal of Media Literacy Education 6(2), 68 - 78.

>Jolls, T. (2007). Second Edition of Literacy for 21st Century: An Overview and Orientation Guide for Media LiteracyEducation.Centerfor Media Literacy.

Jolls, T., \& Sund, M. A. (2007). Questions/TIPS. Los Angeles: Center for Media Literacy.

$>$ Masterman, L. (1989). Teaching the Media. Routledge.

$>$ Milosavljević, S. \& Radosavljević, I. (2013). Osnovi metodologije političkih nauka. Službeni glasnik. $>$ Nielsen, R. K., Fletcher, R., Newman, N., Brennen, J. S., \& Howard, P. N. (2020). Misinformation, Science, and Media - Navigating the 'Infodemic': How People in Six Countries Access and Rate News and Information about Coronavirus. Reuters Institute, University of Oxford. Retrieved April 26, 2020, from https://reutersinstitute.politics.ox.ac.uk/sites/default/files/2020-04/Navigating\%20the\%20 Coronavirus\%20Infodemic\%20FINAL.pdf.

>Pamuk, M. (2020). Portali zarađuju na tvrdnjama da je korona virus izmišljen. MC_ONLINE, E-Bilten. Retrieved Jun 06, 2020, from https://www.media.ba/bs/magazin-novinarstvo/ portali-zaraduju-na-tvrdnjama-da-je-koronavirus-izmisljen.

>Popadić, D., Pavlović, Z. \& Žeželj, I. (2018). Alatke istraživača: metodi i tehnike istraživanja u društvenim naukama. Clio.

>Raskrinkavanje.ba. (2020, May) Retrieved May 20, 2020, from https://raskrinkavanje.ba/ analize-sa-clancima-kategorisanim-kao-lazna-vijest.

>Thoman, E. (1993). Skills and Strategies for Media Education. Retrieved May 05, 2020, from http://www.medialit.org/reading-room/skills-strategies-media-education.

$>$ Thoman, E., \& Jolls, T. (2004). Media Literacy - A National Priority for a Changing World. American Behavioral Scientist, 48(1), 18-29. DOI: 10.1177/0002764204267246.

>Thoman, E., Jolls, T., \& Share, J. (2002). Literacy for The 21st Century: An Overview and Orientation Guidefor Media Literacy Education. Center for Media Literacy.

$>$ Wilson, C., \& Duncan, B. (2009). Implementing Mandates in Media Education: The Ontario Experience. Comunicar, Latin American Scientific Journal of Media Education, 32, 127-140. Retrieved May 05, 2020, from http://www.revistacomunicar.com/pdf/comunicar32-en.pdf. 


\section{NAČIN KORIŠTENJA I VREDNOVANJA INFORMACIJA O KORONAVIRUSU (COVID 19) GRAĐANA BOSNE I HERCEGOVINE U KONTEKSTU PET KLJUČNIH KONCEPATA MEDIJSKE PISMENOSTI}

\section{Dragana Trninić}

SAŽETAK U vrijeme pandemije koronavirusa pokazalo se koliki je značaj medijske pismenosti. Pojavio se velik broj lažnih vijesti te informacija kojima nedostaje kontekst, iako su podaci točni (Arao, 2020). Cilj je rada utvrditi na koji su se način građani Bosne i Hercegovine koristili informacijama o koronavirusu $i$ vrednovali ih, u kontekstu pet ključnih koncepata medijske pismenosti. Rezultati istraživanja, koje je provedeno online, upućuju na to da se većina ispitanika o koronavirusu informirala putem interneta, da ih je zbunjivala velika količina inofrmacija, da često nisu provjeravali informacije i da ne znaju prepoznati uvredljiv sadržaj.

KLJUČNE RIJEČI

BOSNA I HERCEGOVINA, MEDIJSKA PISMENOST, DEZINFORMACIJE, LAŽNE VIJESTI, KORONAVIRUS

Bilješka o autorici

Dragana Trninić :: Fakultet političkih nauka Univerziteta u Banjoj Luci :: dragana.trninic@fpn.unibl.org 